\title{
Influence of post-harvest application of chitosan on physico-chemical changes of apple fruit during storage
}

Sidra Zeb ${ }^{1 *}$, Muhammad Sajid ${ }^{2}$, Syed Tanveer $\mathrm{Shah}^{2}$, Mazhar $\mathrm{Ali}^{3}$, Shahid Ali ${ }^{2}$, Zohra Nawaz ${ }^{2}$, Kamran Rauf ${ }^{2}$, Aamir Khan ${ }^{2}$, Hajra Shah ${ }^{4}$, Syed Aizaz Ali Shah ${ }^{5}$ and Rabia Riaz ${ }^{1}$

1. Hazara Agriculture Research Station, Abbottabad-Pakistan

2. Department of Horticulture, The University of Agriculture Peshawar-Pakistan

3. Agricultural Research Institute, Mingora, Swat-Pakistan

4. Agricultural Research Institute, Tarnab, Peshawar-Pakistan

5. College of Horticulture, Department of vegetable Sciences, China Agricultural University, Beijing-China

*Corresponding author's e-mail: sidrazeb358@gmail.com

Citation

Sidra Zeb, Muhammad Sajid, Syed Tanveer Shah, Mazhar Ali, Shahid Ali, Zohra Nawaz, Kamran Rauf, Aamir

Khan, Hajra Shah, Syed Aizaz Ali Shah and Rabia Riaz. Influence of post-harvest application of chitosan on physico-chemical changes of apple fruit during storage. Pure and Applied Biology. Vol. 9, Issue 4, pp2554-2562. http://dx.doi.org/10.19045/bspab.2020.90271

\begin{tabular}{llll}
\hline \hline Received: 22/04/2020 & Revised: 01/07/2020 & Accepted: 09/07/2020 & Online First: 06/08/2020 \\
\hline \hline
\end{tabular}

\section{Abstract}

Apple due to its climacteric nature lose its quality very rapidly. Chitosan being a non-toxic biodegradable material can be used as coating material for fruits. It would be environmental friendly as compared to other chemicals. Therefore, this experiment was conducted to evaluate the optimum chitosan concentration for retaining the quality of apple fruits for longer time. The fruits were coated with three chitosan concentrations $(0.5,1.0$ and $1.5 \%)$ along with a set of fruits treated with distilled water as control. The fruits when dried were kept in the laboratory at room temperature $\left(18 \pm 2^{\circ} \mathrm{C}\right)$ for 80 days, to study the effect of chitosan concentrations against physiological attributes after every 20 days interval. Both chitosan and storage had significantly influenced all the quality attributes of apples. Fruits coated with $1.5 \%$ chitosan were more firm and had maximum juice content, titratable acidity and ascorbic acid with less weight loss, fruit juice $\mathrm{pH}$, total soluble solids (TSS) and TSS-Acid ratio and these results were at par with the effect of $1.0 \%$ chitosan on the fruits. Regarding storage effect, the fruits analyzed after 80 days showed maximum losses in weight, firmness, percent acidity and Ascorbic acids while pH, TSS and TSS-Acid ratio were found maximum. The interactive effect between chitosan and storage was found non-significant for all the studied attributes. It was concluded from the experiment that apple fruits $\mathrm{Cv}$. Lady William coated with $1.0 \%$ chitosan after harvesting maintains the quality attributes up to 80 days during storage at $18 \pm 2{ }^{\circ} \mathrm{C}$ and $56 \pm 2 \%$ RH.

Keywords: Apple; Chitosan; Climacteric fruit; Coating material; Lady William; Storage

\section{Introduction}

Apple (Malus domestica) belongs to the family Rosaceae. It is native to Eastern Turkey [1]. Apples being highly perishable in nature, there have been almost $25-40 \%$ postharvest losses during its marketing [2]. Despite of losses in quantity, stored apples also have a serious problem of rapidly diminishing nutritional and textural quality [3]. Softening of apple fruits is one of the 
most important problems all over the world. As apples are climacteric fruits, respiration and ethylene synthesis are the primary factors responsible for both qualitative and quantitative losses in the fruits after harvest [4].

Postharvest losses are mostly concerned with harvesting techniques, storage conditions, transportation and improper handling which create surface injuries to the fruits that ultimately give way to microbial attacks and huge losses [5]. The demand for quality and nutritious food for human consumption has motivated the researchers and attracted their attentions towards food preservation. Most of the scientists conducted experiments on coating materials to increase the shelf life of food commodities. Edible coatings being an efficient barrier to diffusion of gases $\left(\mathrm{O}_{2}\right.$ and $\mathrm{CO}_{2}$ ) and resolving issues of aroma and moisture loss $[6,7]$ can be used to enhance shelf life and post-harvest quality of vegetables and fruits [8]. Many researchers have suggested that edible coatings are safe and very effective in preventing perishable food product from deterioration by reducing dehydration, limiting respiration, enhancing texture, maintaining flavor and suppressing microbial growth [9].

Chitosan a non-toxic compound produced by de-acetylation of chitin, collected from fungi and the exoskeleton of crustaceans and insects. It could be one of the best edible coating materials because of its outstanding capability to form an antifungal and antimicrobial film with biodegradability, biocompatibility and non-toxicity to human beings [10]. It creates semi permeable membrane on fruit surface that regulates gaseous exchange and limit transpiration and ripening [11]. Many scientists used chitosan as a surface coating and successfully increased the postharvest life and minimized decay incidence in many fruits, such as strawberry [12], peach [13] and table grape [14]. Beside all these significances, the usage of chitosan as a surface coating is more worth full due to its reasonable cost, effectiveness, easy application and antimicrobial properties $[15,16]$.

Currently there is no report available on chitosan used as a surface coating on apple (Lady William) to retain its nutritional and textural qualities during storage for longer time. Keeping in view the importance of chitosan as a coating material, the current study was conducted to evaluate the optimum coating concentration of chitosan for apple fruits to maximize its postharvest life for longer storage.

\section{Materials and methods}

Apple fruits (cv. Lady William) were harvested at physiologically mature stage from the orchard in Mingora Research Station in Nov, 2016 and brought to the Horticulture Laboratory, The University of Agriculture Peshawar. The fruits having equal sizes and maturity with no abrasions were selected for the current study. Three chitosan concentrations $(0.5,1.0$ and $1.5 \%)$ were applied with the help of soft foam to the fruits while distilled water was treated to the fruits as control treatment. The fruits were stored for 80 days $\left(18 \pm 2{ }^{\circ} \mathrm{C}, 56 \% \pm 2 \mathrm{RH}\right)$ in the laboratory and data were recoded after every 20 days of interval.

\section{Preparing chitosan solution}

For preparing various concentrations of chitosan solution, each chitosan weighed for specific concentration was first dissolved in dilute acid $(\mathrm{HCl})$ placed on magnetic stirrer for several minutes. After proper dissolution distilled water was added to obtain a desirable volume of the solution. Its $\mathrm{pH}$ was adjusted up to 7 by adding $0.1 \mathrm{~N} \mathrm{NaOH}$.

\section{Statistical analysis}

The recorded data were analyzed through Analysis of Variance (ANOVA) procedure for CR design with two factor factorial arrangement. In case data were found significant, means were compared by using Least Significance Differences (LSD) test at 
$5 \%$ level of significance. Statistical software Statistix (8.1) was used for computing ANOVA and LSD test [17].

\section{Results and discussion}

\section{Fruit weight loss}

The data regarding fruit weight loss is shown in (Table 1). Chitosan concentrations and storage duration significantly affected weight loss of the fruits. In fruits, treated with distilled water, maximum weight loss $(8.33 \%)$ was observed, followed by fruits treated with $0.5 \%$ chitosan concentration $(6.86 \%)$, however weight loss was minimum $(5.43 \%)$ in fruits treated with $1.5 \%$ chitosan concentration.

The chitosan concentrations significantly declined weight loss during storage. This might be the reason that chitosan coating acts as a barrier to gaseous exchange and cell wall integration which slow down the evapotranspiration and finally the level of respiration in fruits [18]. Current results are in agreement with [19] that apples coated with various concentration of chitosan showed reduction in weight loss of fruit as compared to un-treated fruits.

Weight loss in fruits was consistently increased during storage. Fruit storage upto 80 days resulted in maximum weight loss $(9.15 \%)$, followed by $(8.50 \%)$ at 60 days of storage, while least weight loss $(3.79 \%)$ was observed at 20 days of storage. Respiration and transpiration has a major role in weight loss of fruits during storage [20]. Other studies also revealed that a steady increase in weight loss of apples was recorded during storage $[21,22]$.

Table 1. Weight loss, Fruit firmness, Juice content, Juice PH, TSS, Titratable acidity, TSS/Acid ratio and Ascorbic acid of apple fruit as affected by chitosan concentration and storage duration

\begin{tabular}{|c|c|c|c|c|c|c|c|c|}
\hline Parameters & \begin{tabular}{|c|} 
Weight \\
Loss \\
$(\%)$
\end{tabular} & $\begin{array}{c}\text { Fruit } \\
\text { firmness } \\
\left(\mathrm{Kgcm}^{-2}\right)\end{array}$ & $\begin{array}{c}\text { Juice } \\
\text { content } \\
(\%)\end{array}$ & $\begin{array}{c}\text { Juice } \\
\text { pH }\end{array}$ & $\begin{array}{c}\text { TSS } \\
\left({ }^{\circ} \text { Brix }\right)\end{array}$ & $\begin{array}{c}\text { Titratable } \\
\text { acidity } \\
(\%)\end{array}$ & $\begin{array}{l}\text { TSS/Acid } \\
\text { ratio }\end{array}$ & $\begin{array}{c}\text { Ascorbic } \\
\text { acid (mg } \\
\left.100 \mathrm{~g}^{-1}\right)\end{array}$ \\
\hline \multicolumn{9}{|c|}{ Treatments } \\
\hline Control & $8.33 \mathrm{a}$ & $4.01 \mathrm{~b}$ & $31.93 \mathrm{c}$ & $4.48 \mathrm{a}$ & $10.60 \mathrm{a}$ & $0.57 \mathrm{c}$ & $19.02 \mathrm{a}$ & $11.87 \mathrm{~b}$ \\
\hline 0.5 & $6.86 \mathrm{~b}$ & $4.32 \mathrm{ab}$ & $35.11 b c$ & $4.44 \mathrm{a}$ & $10.31 \mathrm{ab}$ & $0.60 \mathrm{~b}$ & $17.35 \mathrm{~b}$ & $12.80 \mathrm{ab}$ \\
\hline 1.0 & $6.41 \mathrm{~b}$ & $4.65 \mathrm{a}$ & $37.21 \mathrm{ab}$ & $4.38 \mathrm{~b}$ & $9.91 \mathrm{bc}$ & $0.63 \mathrm{a}$ & $15.88 \mathrm{c}$ & $13.33 \mathrm{a}$ \\
\hline 1.5 & $5.43 \mathrm{c}$ & $4.81 \mathrm{a}$ & $40.24 \mathrm{a}$ & $4.34 \mathrm{~b}$ & $9.58 \mathrm{c}$ & $0.65 \mathrm{a}$ & $14.90 \mathrm{c}$ & $14.00 \mathrm{a}$ \\
\hline LSD (0.05) & 0.88 & 0.54 & 4.96 & 0.06 & 0.55 & 0.025 & 1.07 & 1.28 \\
\hline \multicolumn{9}{|c|}{ Storage duration (Days) } \\
\hline 0 & - & $5.21 \mathrm{a}$ & $42.19 \mathrm{a}$ & $4.31 \mathrm{~d}$ & $9.26 \mathrm{c}$ & $0.69 \mathrm{a}$ & $13.52 \mathrm{e}$ & $14.83 \mathrm{a}$ \\
\hline 20 & $3.79 \mathrm{c}$ & $4.78 \mathrm{ab}$ & $37.34 \mathrm{ab}$ & $4.36 \mathrm{~cd}$ & $9.49 \mathrm{c}$ & $0.64 \mathrm{~b}$ & $14.82 \mathrm{~d}$ & $13.67 \mathrm{ab}$ \\
\hline 40 & $5.58 \mathrm{~b}$ & $4.50 \mathrm{bc}$ & $36.27 \mathrm{~b}$ & $4.41 \mathrm{bc}$ & $9.70 \mathrm{c}$ & $0.60 \mathrm{c}$ & $16.24 \mathrm{c}$ & $13.00 \mathrm{bc}$ \\
\hline 60 & $8.50 \mathrm{a}$ & $4.11 \mathrm{~cd}$ & $32.92 \mathrm{~b}$ & $4.46 \mathrm{ab}$ & $10.66 \mathrm{~b}$ & $0.58 \mathrm{c}$ & $18.56 \mathrm{~b}$ & $12.17 \mathrm{~cd}$ \\
\hline 80 & $9.15 \mathrm{a}$ & $3.63 \mathrm{~d}$ & $31.90 \mathrm{~b}$ & $4.52 \mathrm{a}$ & $11.38 \mathrm{a}$ & $0.55 \mathrm{~d}$ & $20.79 a$ & $11.33 \mathrm{~d}$ \\
\hline LSD (0.05) & 0.88 & 0.60 & 5.54 & 0.07 & 0.61 & 0.028 & 1.20 & 1.43 \\
\hline \multicolumn{9}{|c|}{ Interaction } \\
\hline Conc x S.D & NS & NS & NS & NS & NS & NS & NS & NS \\
\hline LSD (0.05) & NS & NS & NS & NS & NS & NS & NS & NS \\
\hline
\end{tabular}

\section{Fruit firmness $\left({\left.\mathrm{kg} . \mathrm{cm}^{-2}\right)}^{-2}\right.$}

Chitosan coating significantly retained the fruit firmness. Highest fruit firmness (4.81 $\mathrm{kg} . \mathrm{cm}^{-2}$ ) was recorded in fruits coated with $1.5 \%$ chitosan concentration closely followed by fruits treated with $1.0 \%\left(4.65 \mathrm{~kg} . \mathrm{cm}^{-2}\right)$, while lowest fruit firmness $\left(4.01 \mathrm{~kg} . \mathrm{cm}^{-2}\right)$ was noted in fruits treated with distilled water. The retained firmness in apple fruits might be due to low rate of respiration caused by chitosan coating, acted as barrier to gaseous exchange along the fruit surface 
[23]. The results of [19] are also in line with the present finding that nano-chitosan coating decreased the rate of softening in apple fruits as compared to control fruits and thus retained firmness in apples.

Fruit firmness was significantly decreased with storage duration. The highest fruit firmness $\left(5.21 \mathrm{~kg} . \mathrm{cm}^{-2}\right)$ was observed in freshly harvested fruits, which were at par with fruit firmness $\left(4.78 \mathrm{~kg} . \mathrm{cm}^{-2}\right)$ of fruits stored for 20 days, whereas fruits stored up to 80 days had the lowest fruit firmness (3.63 $\mathrm{kg} . \mathrm{cm}^{-2}$ ). This fast decline in firmness during storage may be due to its climacteric nature. The two most important factors for fruit softening are loss of water due to transpiration which results in loss of turgidity and cell wall breakdown due to enzymatic activities [24]. Furthermore, cell wall weakening, cellulose and hemicellulose hydrolysis, loss of membrane integrity as well as starch and pectin depolimerisation causes fruits softening [25]. Our findings are similar with the results of [26] who observed that firmness of two apple cultivars (Jonathan and Red Delicious) decreased when increased the storage duration.

\section{Percent juice content}

Chitosan application significantly retained the juice content in the fruits during storage. Maximum juice content (40.24\%) was recorded in fruits treated with $1.5 \%$ chitosan concentration followed by fruit treated with $1.0 \%$ (37.21\%), however, minimum juice content $(31.93 \%)$ was obtained in control fruits, treated with distilled water. Chitosan acts as a barrier for loss of water vapors from the fruit surface, leading to minimum fruit weight loss. In this way fruit remains fresh for longer time. Similarly, the application of chitosan on mango and litchi fruits had higher juice content at the end of storage period [27, 28]. Current results are in agreement with [29] that percent juice content was significantly high in chitosan coated apples as compared to control fruits.
Fruit juice content reduced rapidly with storage intervals. The highest juice content $(42.19 \%)$ in fruits was observed at freshly harvested stage, followed by $(37.34 \%)$ in fruits stored for 20 days, while the lowest juice content $(31.90 \%)$ was detected in fruits stored for 80 days. This decline in juice content might be due to the water loss from the fruit surface [30]. Perishable nature of fruits is also an important factor which contributes in decreasing juice content as storage time is prolonged. These losses are high in fruits having bruised or damaged surfaces [31].

\section{Fruit juice pH}

Surface coating with chitosan significantly affected $\mathrm{pH}$ of the fruits. Maximum $\mathrm{pH}$ (4.48) was recorded for control fruits, closely followed by $\mathrm{pH}$ (4.44) recorded in fruits treated with $0.5 \%$ chitosan, however minimum $\mathrm{pH}$ (4.34) was noted in fruits treated with $1.5 \%$ chitosan. As chitosan has a selective permeability to gases which resulted in $\mathrm{CO}_{2}$ accumulation inside the fruit and decreases $\mathrm{pH}$. One study revealed a retained juice $\mathrm{pH}$ of strawberry by postharvest application of edible coating materials (chitosan) during storage [32]. Similarly, the $\mathrm{pH}$ of peach fruits were also retained by post-harvest application of edible coating material [20].

The $\mathrm{pH}$ of the fruit juice raised significantly with storage of the apples. The fruits stored upto 80 days had the highest $\mathrm{pH}$ value (4.52), followed by $\mathrm{pH}$ (4.46) stored for 60 days, while the lowest $\mathrm{pH}$ (4.31) was noted for freshly harvested fruits. This gradual rise of $\mathrm{pH}$ in fruits might be due to a decrease in acidity of the fruits because of the biochemical changes during storage. According to [33] a rise in $\mathrm{pH}$ is due to the hydrolysis of pectin. The observations are in line with the findings of [34] who stated that $\mathrm{pH}$ of apples increased as storage was prolonged. 


\section{Total soluble solids ( ${ }^{\circ}$ Brix)}

Total soluble solids (TSS) were significantly influenced with chitosan treatment to the fruits. Maximum TSS (10.6 ${ }^{\circ}$ Brix) was recorded in control fruits closely followed by TSS $\left(10.3{ }^{\circ}\right.$ Brix $)$ in fruits treated with $0.5 \%$ chitosan. The lowest TSS $\left(9.6{ }^{\circ}\right.$ Brix) was found in fruits treated with $1.5 \%$ chitosan. Retained TSS content might be due the postharvest application of chitosan film which acts as a pore barrier and selectively permeates $\mathrm{C}_{2} \mathrm{H}_{4}, \mathrm{CO}_{2}$ and $\mathrm{O}_{2}$ leading to a reduced rate of respiration, transpiration and ethylene production. Olive oil residues incorporated with chitosan films retained the TSS content in both apple and strawberry fruits [35]. Similarly, lower TSS content was observed in strawberry fruits coated with chitosan-beeswax [36].

TSS gradually raised in the fruits with storage duration. High values of TSS (11.4 ${ }^{\circ}$ Brix) were recorded in fruits stored for 80 days, followed by $\left(10.7^{\circ}\right.$ Brix) stored for 60 days, while the lowest TSS (9.3 ${ }^{\circ}$ Brix) was observed in freshly harvested fruits. This gradual increase in TSS of fruits with storage interval might be due to hydrolysis of polysaccharides and concentrated juice content as a result of dehydration. A gradual increase in TSS content was also recorded in apple fruits during storage by application of coating and wrapping materials [37]. Similarly, [38, 39] also worked on apple fruits and recorded a gradual increase in total soluble solids by increasing storage duration.

\section{Titratable acidity (\%)}

Highest titratable acidity $(0.65 \%)$ was recorded in fruits treated with $1.5 \%$ chitosan, followed by titratable acidity $(0.63 \%)$ in fruits treated with $1.0 \%$ chitosan. The lowest titratable acidity $(0.57 \%)$ was noted in fruits treated with distilled water. Chitosan coating slowed down the gaseous exchange which resulted in $\mathrm{CO}_{2}$ accumulation in the fruits, which led to slowing down the repining process and ethylene production, thus retained the titratable acidity during storage $[40,41]$. In a study, Post-harvest application of chitosan at 0.2 and $0.5 \%$ significantly retained the titratable acidity in apple fruits during storage [19]. Similar results were examined by [32] who observed a slow decrease in chitosan-beeswax coated apple and strawberry fruits.

Titratable acidity was decreased with storage time. Highest titratable acidity $(0.69 \%)$ was recorded in freshly harvested fruits, followed by $(0.64 \%)$ of fruits at 20 days of storage, while the lowest titratable acidity $(0.55 \%)$ was observed in fruits stored for 80 days. This decrease in titratable acidity might be due to breakdown of organic acids in respiration process during storage [42].

\section{TSS /Acid ratio}

Maximum TSS/acid ratio (19.0) was recorded in control fruits, followed by TSS/acid ratio (17.4) of apple fruits treated with $0.5 \%$ chitosan. Whereas, the lowest TSS/acid ratio (14.9) was noted in fruits coated with $1.5 \%$ chitosan. Chitosan coating to fruits resulted in $\mathrm{CO}_{2}$ accumulation internally in fruit tissues which ultimately retained both the titratable acidity and TSS of the fruit during storage duration [41]. The findings of our work are in line with the findings of [43] who reported that by applying chitosan material on fruits as a coating material, the respiration and water loss decreased.

TSS/acid ratio of the fruits was increased with storage duration. Maximum TSS/acid ratio (20.8) was noted at 80 days of storage, followed by (18.6) at 60 days of storage, while, the lowest TSS/acid ratio (13.5) was recorded in fruits at freshly harvested stage. The increased TSS/acid ratio in fruits during storage is due to degradation of ascorbic acid and increase in TSS [44]. Another study revealed that increase in TSS/acid ratio during storage might be due to the hydrolysis of polysaccharides; conversion of starch into sugar [45]. Also [46] examined a high 
TSS/acid ratio in 'Valencia' oranges with the passage of time.

\section{Ascorbic acid (mg 100g-1)}

Highest ascorbic acid (14.0 mg $\left.100 \mathrm{~g}^{-1}\right)$ was recorded in the fruits treated with $1.5 \%$ chitosan, which was at par with ascorbic acid $13.3 \mathrm{mg}_{100 \mathrm{~g}^{-1}}$ ) in fruits coated with $1.0 \%$ chitosan. The lowest value for ascorbic acid $\left(11.9 \mathrm{mg} 100 \mathrm{~g}^{-1}\right)$ was observed in control fruits. Chitosan coating reduces oxygen diffusion, slowing down the respiration rate, which ultimately delays the deteriorative oxidation reaction of ascorbic acid of fruit [47]. The post-harvest application of chitosan significantly reduced vitamin $\mathrm{C}$ losses during storage [48]. Similarly, [49] observed better retention of vitamin $\mathrm{C}$ in edible coated sweet orange fruits. Similar effect was also observed in chitosan coated pear fruits [50]. The ascorbic acid was decreased in fruits with storage intervals. Maximum ascorbic

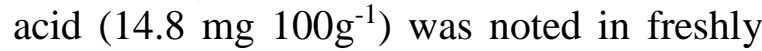
harvested fruits, followed by ascorbic acid $\left(13.7 \mathrm{mg}^{100 \mathrm{~g}^{-1}}\right)$ at 20 days of storage, while the minimum ascorbic acid $\left(11.3 \mathrm{mg}^{\left.100 \mathrm{~g}^{-1}\right)}\right.$ was noticed in fruits stored for 80 days. Ascorbic acid is a bioactive compound which decreases with the passage of time [51]. The decrease in ascorbic acid content might be due to loss of antioxidants activity during post-harvest storage [52]. A gradual decrease in ascorbic acid of apple was observed in several apple cultivars during storage [53].

\section{Conclusion and recommendation}

The post-harvest application of Chitosan at $1.5 \%$ concentration to apples significantly retained fruit firmness, $\mathrm{pH}$, juice content, total soluble solids, titratable acidity, ascorbic acid with minimum weight loss of which were statistically at par with results obtained when fruits were treated $1.0 \%$ chitosan. All the quality attributes of apple significantly decreased with increasing the storage duration for 80 days at room temperature $\left(18 \pm 2^{\circ} \mathrm{C}\right)$ and R.H $(56 \pm 2 \%)$. The interactive effect of chitosan and storage duration for all the quality attributes was found non-significant. The post-harvest application of chitosan at $1.0 \%$ could be used for apple fruit $\mathrm{Cv}$. Lady Willam to maintain the physico-chemical parameters during storage.

\section{Authors' contributions}

Conceived and designed the experiments: S Zeb, M Sajid \& ST Shah, Performed the experiments: S Zeb, M Ali, Z Nawaz, S Ali \& A Khan. Analyzed the data: M Ali, S Zeb \& K Rauf. Contributed reagents/ materials/ analysis tools: M Sajid, H Shah \& SAA Shah. Wrote the paper: S Zeb, M Ali \& R Riaz.

\section{References}

1. Morgan J \& Richards A (1993). The book of apples. Ebury Press, London.

2. Raja MB \& Khokhar KM (1993). Postharvest horticulture technology and its future prospects. In Proceeding of first international horticulture seminar 265-277.

3. Kov E \& Felf E (2003). Investigating the firmness of stored apples by nondestructive method. Acta Hortic 59: 257260.

4. Kader AA (2002). Postharvest technology of horticultural crops. 3rd ed. University of California, Oakland, Extension Publication 296.

5. Ilyas MB, Ghazanfar MU, Khan MA, Khan CA \& Bhatti MAR (2007). Postharvest losses in apple and banana during transport and storage. Pak J Agric Sci 44(3): 534.

6. Cuq B, Gontard N \& Guilbert S (1995). Edible films and coatings as active layers. In M.L. Rooney (Ed.), Active Food Packaging. London, U.K. Springer Verlag 111-135.

7. Fernandez-Alvarez M (2000). Active food packaging. Food Sci Technol Inter 6(2): 97-108.

8. Vernon EJ, Pez LJ \& Garc HS (1999). Uso de recubrimientos biopolimericos comoco adyuvantes en el tratamiento 
fitosanitario de mango (Mangifera indica, Variedad Manila). Revista Dintel 7(5): 42-48.

9. Ozdemir AE, Candır EE, Kaplankıran M, Soylu EM, Sahinler N \& Gul A (2010). The effects of ethanol-dissolved propolis on the storage of grapefruit cv. Star Ruby. Turk J Agric For 34: 155162.

10. Peniche C, Arguelles-Monal W, Peniche H \& Acosta N (2003). Chitosan: an attractive biocompatible polymer for micro encapsulation. Macromol Biosci 3(10): 511-520.

11. Jiang YM, Li JR \& Jiang WB (2005). Effects of chitosan coating on shelf life of cold stored litchi fruit at ambient temperature. Food Sci Technol 38: 757761.

12. Du JM, Gemma H \& Iwahori S (1997). Effects of chitosan coating on the storage of peach, Japanese pear, and kiwifruit. $J$ Japanese Soc Hortic Sci 66: 15-22.

13. El-Ghaouth A, Arul J, Ponnamapalam R \& Boulet M (1991). Chitosan coating effect on storability and quality of fresh strawberries. J Food Sci 56: 1618-1620.

14. Romanazzi G, Nigro F \& Ippolito A (2003). Short hypobaric treatments potentiate the effect of chitosan in reducing storage decay of sweet cherries. Postharvest Biol Technol 29: 73-80.

15. Kim KW, Min BJ, Kim YTY, Kimmel RM, Cooksey K \& Park SI (2011). Antimicrobial activity against food borne pathogens of chitosan biopolymer films of different molecular weights. Food Sci Tech 44: 565-569.

16. Wang SY \& Gao H (2013). Effect of chitosan based edible coating on antioxidants, antioxidant enzyme system, and postharvest fruit quality of strawberries (Fragaria aranassa Duch.). Food Sci Technol 52: 71-79.

17. Jan MT, Shah P, Hollington PA, Khan MJ \& Sohail Q (2009). Agriculture
Research: Design and Analysis. ${ }^{\text {st }}$ Ed. Dept. of Agronomy, The Uni of Agric Peshawar Pakistan.

18. Butler BL, Vergano PJ, Testin RF, Bunn JM \& Wiles JL (1996). Mechanical and barrier properties of edible chitosan films as affected by composition and storage. J Food Sci 61: 953-956.

19. Sahraei A, Gardesh K, Badii F, Hashemi M, Ardakani AY, Maftoonazad N \& Gorji AM (2016). Effect of nanochitosan based coating on climacteric behavior and post harvest shelf life extension of apple cv. GolabKhonaz. Food Sci Tech 70: 33-40.

20. Maftoonazad N, Ramaswamy HS \& Marcotte M (2008). Shelf life extension of peaches through sodium alginate and methyl cellulose edible coatings. Inter $J$ Food Sci Technol 43: 951-957.

21. Bidabe B (1970). Apple quality in relation to picking and eating time. Aroboric fruit. Aust J Exp Agric 17(196): 26-28.

22. Attia MN (1995). Effect of postharvest treatments on fruit losses and keeping quality of Balady oranges through cold storage. Alexandria J Agric Res 40(3): 349-363.

23. Salunkhe DK, Boun HR \& Reddy NR (1991). Storage processing and nutritional quality of fruits and vegetables. Boston, MA. USA: CRC Press Inc 156-161.

24. Kweon H, Yul KH, Park RO \& Youn M (1998). Effects of CA storage procedures and storage factors on the quality and the incidence of physiological disordes of "Fuji" apples. J Kor Soc Hortic Sci 39(1): 35-39.

25. Seymour GB, Taylor JE \& Tucker GA (1993). Biochemistry of fruit ripening. London: Chapman and hall Publishers. 454.

26. Yuen $\mathrm{CMC}$, Haynes $\mathrm{Y} \&$ Warton $\mathrm{M}$ (1995). Consumer acceptance of 
Jonathan and Delicious apples in relation to fruit maturity and physio-chemical attributes. Dept. of Food Sci. and Tech., Univ.Of New South Wales, Sydeny Australia. Asian Food J 10(4): 139-144.

27. Chien PJ, Sheu F \& Lin HR (2007). Coating citrus (Murcott tangor) fruit with low molecular weight chitosan increases postharvest quality and shelf life. Food Chem 100: 1160-1164.

28. Dong HQ, Cheng LY, Tan JH, Zheng KW \& Jiang YM (2004). Effects of chitosan coating on quality and shelf life of peeled litchi fruit. J Food Eng 64: $355-358$.

29. Susaj E, Mustafa S, Kallac I, Susaj L \& Susaj ML (2014). Fruit quality parameters and shelf life of "Golden Delicious" Apple. Online Inter Interdisciplinary Res $J$ 4(5): 34-42.

30. Dzonova M, Petrovska V, Vesova N \& Baurer O (1970). Change in some constituents of apple kept in cold chamber and in refrigeration. Hort Absts 23: 159-68.

31. Dang KTH, Singh Z \& Winny AES (2008). Edible coatings influence fruit ripening, quality and aroma biosynthesis in mango fruit. J Agric Food Chem 56:1361-1370.

32. Gol NB, Patel PR \& Rao TVR (2013). Improvement of quality and shelf-life of strawberries with edible coatings enriched with chitosan. Postharvest Biol Tech 85: 185-195.

33. Imran A, Khan R \& Ayub M (2000). Effect of added sugar at various concentration on the storage stability of guava pulp. Sarhad J Agric 16(1): 89-93.

34. Khalid ZM (1974). Studies on the extension of storage life of some important mango varieties of punjab. M.s.c. thesis, Deptt of Hort, Uni of Agric Faislabad.

35. Khalifa I, Barakat H, El-Mansy HA \& Soliman SA (2016). Improving the shelf life stability of apple and strawberry fruits applying chitosan-incorporated olive oil processing residues coating. Food Pack Shelf Life 9: 10-19.

36. Velickova E, Winkelhausen E, Kuzmanova S, Alves VD \& MoldaoMartins M (2013). Impact of chitosanbeeswax edible coatings on the quality of fresh straw- berries (Fragaria ananassa cv Camarosa) under commercial storage conditions. Food Sci Technol 52: 80-92.

37. Hayat I, Masud T \& Rathore HA (2005). Effect of coating and wrapping material on shelf life of apple. Inter J Food Safety 5: 24-34.

38. Farooqi WA \& Hall EG (1973). Effect of wax coating on apple and pears during storage and ripening. Aust $J$ Exp Agric 13(2): 200.

39. Wills RBH, Banbridge PA \& Scott KJ (1980). Use of flesh firmness and other objective test to determine consumer acceptibility of delicious apple. Aust $J$ Exp Agric Animal Husbandry 20(103): 252-256.

40. Jongsri P, Wangsomboondee T, Rojsitthisak P \& Seraypheap K (2016). Effect of molecular weights of chitosan coating on postharvest quality and physicochemical characteristics of mango fruit. Food Sci Technol 73: 2836.

41. Ali A, Muhammad MTM, Sijam K \& Siddiqui Y (2011). Effect of chitosan coatings on the physicochemical characteristics of eksotika II papaya (Carica papaya L.) fruit during cold storage. Food Chem 124: 620-626.

42. Valero D, Diaz-Mulaa HM, Zapataa PJ, Guillen F, Martinez-Romero D, Castillo S \& Serrano M (2013). Effect of alginate edible coating on preserving fruit quality in four plum cultivars during postharvest storage. Postharvest Biol Technol 77: 16. 
43. Bai RK, Huang MY \& Jiang YY (1988). Selective permeabilities of chitosanacetic acid complex membrane and chitosan-polymer complex membrane for oxygen and carbon dioxide. Polym Bull 20: 83-88.

44. Shahid MN \& Abbasi NA (2011). Effect of bee wax coatings on physiological changes in fruits of sweet orange cv. Blood red. Sar J Agri 27(3): 385-394.

45. Carrillo LA, Valdez JB, Rojas R, Yahia EM \& Gomas JA (1995). Ripening and quality of mangoes affected by coating with "Samper Fresh" on Tropical Fruits. Acta Hort 370: 203-216.

46. Manzano JE \& Diaz A (2001). Effect of storage time, temperature and wax coating on the quality of fruits of 'Valencia' orange (Citrus sinensis L.). Proc. Int'l. Soc. Trop. Hort. 44: 24-29.

47. Atress ASH, El-Mogy MM, AboulAnean HE \& Alsaniu BW (2010). Improving strawberry fruit storability by edible coating as a carrier of thymol or calcium chloride. J Hortic Sci Ornam Plants 2: 88-97.

48. Pushkala R, Raghuram PK \& Srividya N (2013). Chitosan based powder coating technique to enhance phytochemicals and shelf life quality of radish shreds. Postharvest Biol Technol 86: 402-408.
49. Adetunji CO, Fawole OB, Arowora KA, Nwaubani SI, Ajayi ES, Oloke JK, Majo-lagbe ON, Ogundele BA, Aina JA \& Adetunji JB (2012). Quality and safety of Citrus Sinensis coated with hydroxypropylmethyl cellulose edible coatings containing Moringa Oleifera extract stored at ambient temperature. Global J Sci Front Res Biol Technol Genet 12: 29-33.

50. Xiao-Hong K, Guo W, Guo R, Li X \& Xue Z (2014). Effects of chitosan, calcium chloride, and pullulan coating treatments on antioxidant activity in pear cv. "Huang guan" during storage. Food Bioprocess Tech 3(7): 671-681.

51. Adisa VA (1986). The influence of molds and some storage factors on the ascorbic acid content of orange and pineapple fruits. Food Chem 22:139146.

52. Davey MW, Montagu MV, Inze D, Sanmartin M, Kanellis A, Smirnoff N, Benzie IJJ, Strain JJ, Favell D \& Fletcher J (2000). Plant L-ascorbic acid: chemistry, function, metabolism, bioavailability and effects of processing. J Sci Food Agri 80: 825-860.

53. Jan I \& Rab A (2012). Influence of storage duration on physio-chemical changes in fruit of apple cultivars. $J$ Animal Plant Sci 22(3): 708-714. 